\title{
抄紙機カンバスの最近の技術動向
}

\author{
敷島カンバス株式会社技術部 住 吉 誠
}

\section{The Latest Technology on Dryer Fabric for Paper Machine}

\author{
Makoto Sumiyoshi \\ Engineering Department Shikishima Canvas Co., Ltd.
}

\begin{abstract}
Dryer Fabric has a lot of functions, and especially following four functions are very important.

1. To expedite sheet drying.

2. To transfer sheet from wet end to dry end.

3. To prevent sheet from wrinkle.

4. To improve sheet quality.

The proper selection of Dryer Fabric enables to make sheet quality better and also have an great influence on steam comsumption and operating efficiency.

Dryer fabric is very important in the dry part and indispensable to get high quality sheet.

This article refers to the latest technology on Dryer Fabric, and we hope this article is instructive to sheet making.

Keywords: Development of Dryer Fabric for Single Tier Dryer Section, Countermeasure for abrasive edge damage of Dryer Fabric, Countermeasure for contamination of Dryer Fabric
\end{abstract}

\section{1.はじめに}

ドライヤーカンバスはプレスパートから運ばれてき た湿紙を受け取り，(1)ペーパードライヤー（以下 PD と略す）間を円滑に運搬し断紙やしわの発生を防止す る，(2湿紙をPD に圧着させ熱伝達を高め乾燥を促進 させると同時に所定の紙質に仕上げる，などの重要な 機能を有している。

カンバスの適否は紙の品質を決定づけ, 抄紙機の蒸 気原単位や操業性にも大きな影響を及ぼす。

カンバスは, 純綿製平織カンバスに始まり, 多層織 カンバス, 綿・合成繊維の混織カンバス, 継手の採用, プラスチックカンバス，ニードルカンバス，と常に抄 紙機の目ざましい技術革新と共に歩み続けてきた。

ドライパートには欠くことのできない重要な用具で あるカンバスについて, 最近の技術情報を提供し参考 に供したい。

\section{2. トータル単列ドライヤー用カンバスの開発}

\section{1 シングルカンバス}

多筒式のドライパートでは一般的にカンバスは図 1 の通り，上部の PD 群と下部の PD 群にそれぞれ掛入 れられて使用される。

湿紙は図 2 の通り，圧着とフリー走行の繰返しによ って水分が除去されていく。抄紙機の高速化に伴い湿 紙水分率の高いウェットエンドでは, PD 間のフリー ラン部分でフラッタリングによる断紙や湿紙耳部のし わが多発した。

その対策で考案されたのがシングルカンバス方式で ある。この方式は, 上下の PDに連続して一枚のカン バスを掛ける方法で, 湿紙は入口から出口までカンバ スに保持された状態で一緒に走行する。上下部のいず れかで湿紙はカンバスによって PD に圧着され, 一方 ではカンバスが直接 PD に接触し湿紙がカンバスの外 側を走行する。 
図 3 が標準夕イプのシングルカンバス方式である。 これによって湿紙のフリーランがなくなりフラッ夕リ ングが解消し, 断紙の発生回数が大幅に減少し運転効 率の向上と共にスピードアップが達成された。

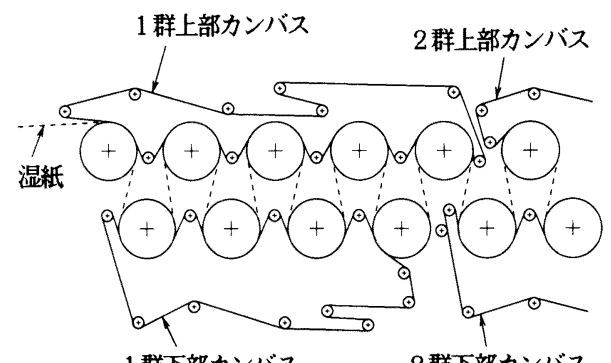

1 群下部カンバス

2 群下部カンバス

図 1 多筒式ドライヤーのカンバスラン

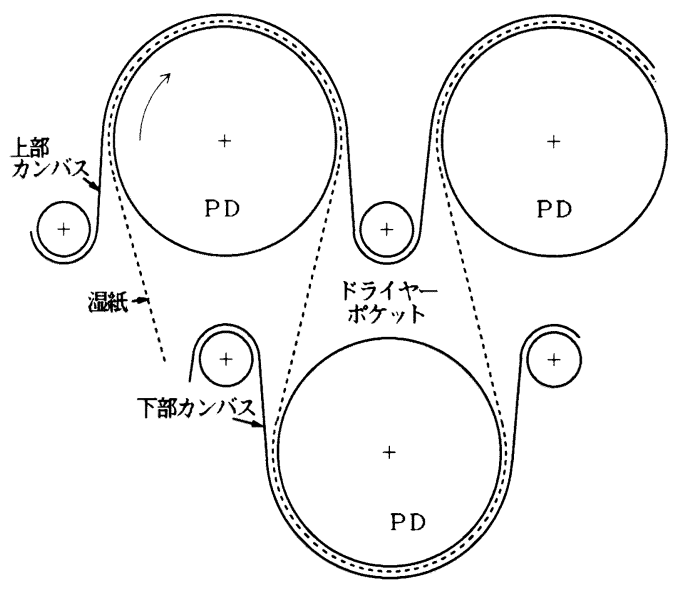

図 2 湿紙の乾燥サイクル

\section{2 単列ドライヤー}

抄紙機の高速化と安定操業に非常に貢献したシング ルカンバス方式も， $1,000 \mathrm{~m} / \mathrm{min}$ 以上へのスピード 化が進む中で更なる改善点が指摘された。

(1)湿紙とカンバスの密着性に限界もあり, 湿紙の密 着性向上対策でブローボックスなどの付属設備が 必要となった。

(2)カンバスが直接タッチする PDの乾燥寄与率は極 めて低く, 乾燥能力が低下した。

(3)損紙の PD への巻付きなどによって, ギヤのトラ ブル発生が愻念された。

これらの問題点を改善する方法として図40通り単 列ドライヤー（シングルデッキドライヤー）が開発さ れた。この方式は, $\mathrm{PD}$ が単列で $\mathrm{PD}$ とD間にはバ キューム能力を有するロールが設置され, 湿紙をカン バスに密着させる設計であった。

単列ドライヤーも最初はシングルカンバス方式と同 様にウェットエンドのみに採用された。その後この単 列ドライヤーは, フラッタリングの対策のみならず, 乾燥中の湿紙を常に拘束し緊張乾燥を実現するもので あるとの研究結果などにより, トータル的なシステム として改善進歩した。図 5 にサイズプレスまでのプレ ドライヤー全群に単列ドライヤーを採用した実施例を 示す。

\section{3 トータル単列ドライヤー用カンバスの機能}

カンバスは一般的に, (1)耐久性に富むこと, (2)寸法 安定性や走行性が良いこと，(3)表面平滑性に富むこと， (4)乾燥性を高める適度の通気性を有すること, (5)紙質 を損なわない表面性で丈夫な継手を備えていること, などの特性が要求される。

トータル単列ドライヤー用カンバスはこれらの特性

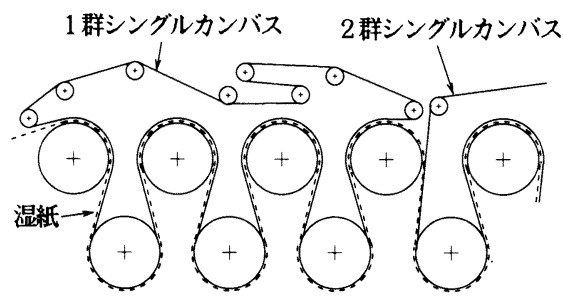

図 3 シングルカンバス方式

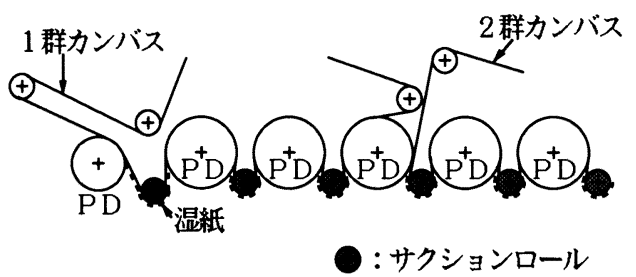

図 4 単列ドライヤー群
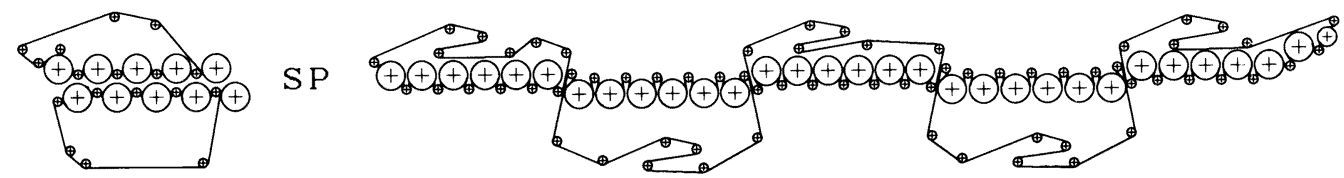

図 5 トータル単列ドライヤー 
に加えて, 設備にマッチした次の機能が必要である。 (1) サクションロールの吸引効果を十分に発揮でき る適度な通気性

図6の通り，PDから PD までの間にサクションロ 一ルが設置され，湿紙はカンバスに密着することにな る。湿紙とカンバスが密着することによって，湿紙の 高速安定走行と緊張乾燥などの各種メリットが得られ るものであり, 密着性をより高める通気度設定が最優 先課題である。

シングルカンバスでの実績と経験に加え，各種の調 查結果より, トータル的な単列ドライヤー用カンバス の通気度は $2,000 \sim 3,000 \mathrm{cc} / \mathrm{min} / \mathrm{cm}^{2}$ の範囲が最適 との結論に至った。一般的な高速抄紙機では, 表 1 に 示すカンバス通気度モデルの通り，ウェットエンドは 通気度を押さ之，乾燥の進行に伴い通気度を高めてい る。しかし, 単列ドライヤ一用のカンバスは, 乾燥性 より密着性の保持が最も重要な条件であり, ウェット エンドからドライエンドまで一定の通気度が安全であ ると言える。

(2) 湿紙にストレッチを与えない範囲のカンバスの 厚さ

シングルカンバスでは一方の PD 群で湿紙がカンバ スの外側を走行するため, 湿紙にストレッチが加わり スリップなどによって紙粉の発生量が多くなった例が

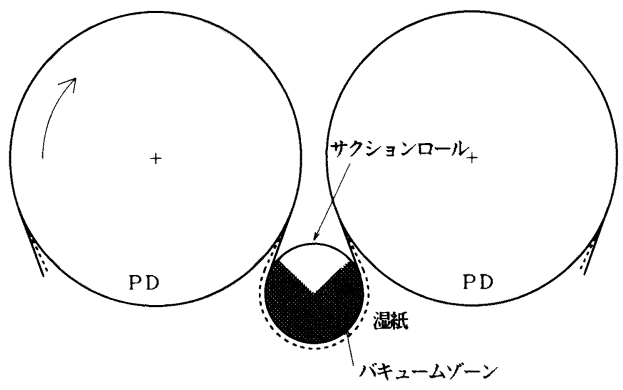

図 6 PD とサクションロール
ある。このため，シングルカンバスは薄く仕上げるよ うに工夫されている。

単列ドライヤーの場合, 図 7 の通り PDよりもかな り小径のロールを通過するため, 湿紙に遠心力が加わ り PDに移動する手前で密着性が低下し，しわや断紙 が䯚念される。特に乾燥が進み湿紙の伸縮性が低下す るドライエンドでは, 厚さの影響が増幅することが推 定される。このため, 継手・表面性・寸法安定性・強 度などに悪影響を及ぼさない範囲で，極力薄く仕上げ ることを目標とした。目標設計值を $2 \mathrm{~mm}$ 以下の厚さ とした。

（3）ソフトタッチで表面性に優れていること

ノードロー方式で湿紙はドライヤー入口から出口ま でカンバスに完全に拘束される。特に群間での湿紙は, 図 8 の通り両サイドのカンバスでサンドイッチ状に挟 まれて受け渡しを完了する。このため, 湿紙にピンホ ールや断紙が発生しないように, ソフトタッチで表面 平滑性に優れていることが必要となる。

ニードルカンバスやそれに近い表面特性を有する組 織設計で開発した。

(4) 精巧でコンパクトな継手

本体の表面性と同様に継手の仕上がり状態も重要で

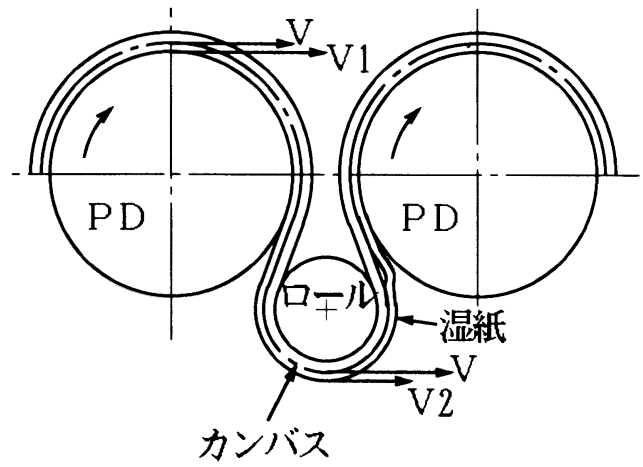

図 7 湿紙とカンバススピードの関係

表 1 カンバス通気度モデル $\left(\mathrm{cc} / \mathrm{min} / \mathrm{cm}^{2}\right)$

\begin{tabular}{|c|c|c|c|c|c|c|c|c|c|}
\hline \multirow{3}{*}{$\begin{array}{c}\text { 新聞用紙 } \\
1,200 \\
(\mathrm{~m} / \mathrm{min})\end{array}$} & & 1 群 & 2 群 & 3 群 & 4 群 & 5 群 & & & \\
\hline & 上部 & \multirow{2}{*}{$\begin{array}{c}1,500 \\
\text { (シングル) }\end{array}$} & \multirow{2}{*}{$\begin{array}{c}2,000 \\
(\text { シングル) }\end{array}$} & 4,000 & 6,000 & 6,000 & & & \\
\hline & 下部 & & & 4,000 & 6,000 & 6,000 & & & \\
\hline \multirow{3}{*}{$\begin{array}{c}\text { コート原紙 } \\
1,100 \\
(\mathrm{~m} / \mathrm{min})\end{array}$} & & 1 群 & 2 群 & 3 群 & 4 群 & 5 群 & 6 群 & 7 群 & 8 群 \\
\hline & 上部 & \multirow{2}{*}{$\begin{array}{c}2,000 \\
\text { (シングル) }\end{array}$} & \multirow{2}{*}{$\begin{array}{c}2,000 \\
\text { (シングル) }\end{array}$} & 4,000 & 8,000 & 8,000 & 10,000 & 6,000 & 10,000 \\
\hline & 下部 & & & 4,000 & 8,000 & 8,000 & 10,000 & 6,000 & 10,000 \\
\hline
\end{tabular}




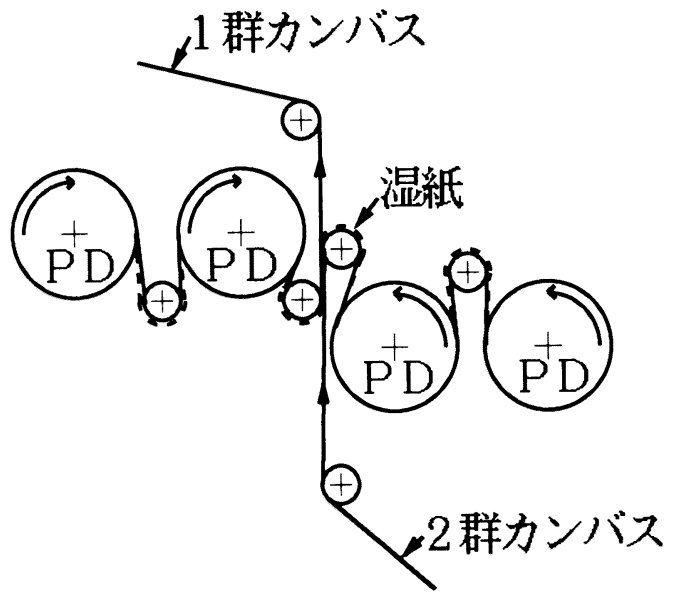

図 8 単列ドライヤーの群間

ある。断紙は勿論のこと, 乾燥むらやマークなどの久 点が発生しないように重視した，コンパクトな継手が 必要である。従来の継手よりも精巧な機能が必要であ ることに加え，カンバス本体の厚さも薄いために種々 検討のうえ工夫した。

カンバス本体のタテ糸でループを形成したループシ 一ムタイプで，継手部が本体と同組織で表面性・曆 さ・通気度が均一なエンドレスに近い継手を開発した。

(5) カンバスの着色

ドライパートで断紙が発生すると，損紙の巻き込み などによっては大きな事故につながるケースがある。 断紙の検知方法としては, PD 間で湿紙がフリー走行 する位置に光電管が設置されているケースが一般的で ある。湿紙が切れると光線を受光器に受光させて, 湿 紙をドライパートの直前でカットすると同時に，運転 を停止するようにセットされている。

ところが, トータル的な単列ドライヤーの場合は, 湿紙とカンバスが一緒に走行するため湿紙のフリーラ ンがなくなり, 従来の透過光方式の断紙検知手段が採 用できない。そこでカンバスを着色し一緒に走行する 湿紙に投光して，その反射光を受光し，通紙時と断紙 時の反射光の光量差を感知する方式を採用して，断紙 を検知することにした。標準白板紙と，紺色・薄紺 色・橙色・薄茶色・黑色など各種色彩のカンバスを準 備して分光反射曲線を測定した。

結果は図9の通りであり，湿紙が白色系であれば， 黒色系統の色彩でカンバスを着色しておけば最効果 的であることが確認できた。

\section{4 トータル単列ドライヤー用カンバスの確立}

国内にトータル的な単列ドライヤーを備えな抄紙機

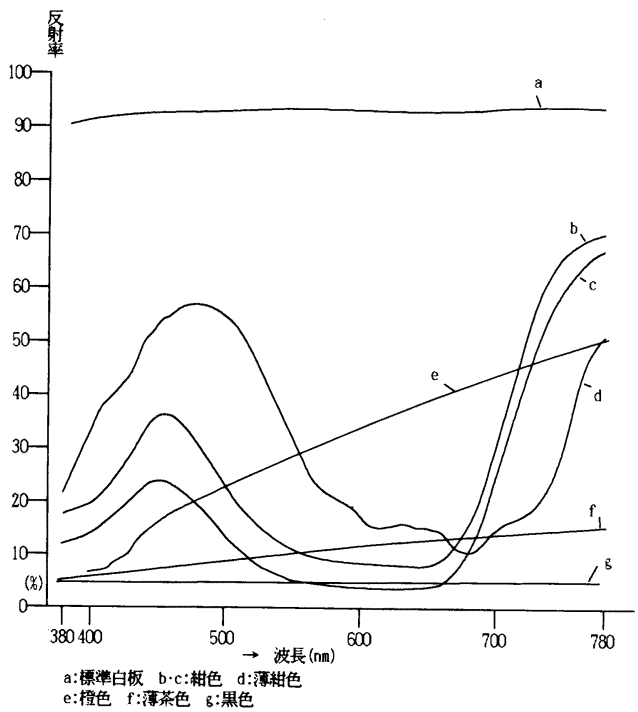

図 9 各種色彩の分光反射曲線

が 3 台建設されることになった。1 台目は機幅 5,800 $\mathrm{mm}$ の上質紙とコート原紙併抄マシン，2台目は機幅 6,250 mmのコート原紙マシン, 3 台目は機幅 9,000 $\mathrm{mm}$ の新聞用紙マシンであった。

(1) 上質紙及びコート原紙マシン

1 台目と 2 台目は同系統の抄物であり表 2 の通りほ ぼ同じスペックで納入することになった。いずれもト ータル単列ドライヤー専用に開発したカンバスで，1 〜2 群は織目のない表面性と平滑性が特長のニードル カンバス，3〜6群は夕テ糸に薄手扁平モノを配した 扁平カンバスであった。

(2) 新聞用紙マシン

上質紙までの厳しい表面平滑性の要求はなく，むし ろ広幅と高速の条件を加味し開発した。1～5群まで の全パートを同一仕様とし，表 3 の通り扁平糸夕イプ で組織も三重織とした。

(3) 使用結果

3 台の抄紙機は平成 2 年 3 年にかけて順調にス夕 一トアップした。カンバスはいずれも表面性・走行 性・寸法安定性などのトラブルは皆無で順調であった。 しかし，計画抄速に近づいた時点で図 10 のように湿 紙にしわが発生した抄紙機もあった。海外のトー夕ル 単列ドライヤーでも同様に湿紙の膨らみやしわが発生 していたことを，調査によって確認していた。

しわの発生はドライヤーパートの後半で，しわの状 態は(1)サクションロールの前後の膨らみ状のしわ，(2) 幅方向の不均一さに起因すると思われるサクションロ 一ル部分での横方向に流れるしわ，であった。カンバ 
表 2 上質紙及びコート原紙マシン用カンバス（代表例）

\begin{tabular}{|c|c|c|c|c|}
\hline \multicolumn{3}{|c|}{ パート } & $1 \cdot 2$ 群用 & 3〜6 群用 \\
\hline \multicolumn{2}{|c|}{ 品 } & & NM-261 C & FB-823 RC \\
\hline \multicolumn{2}{|c|}{ 組 } & & バットオンメッシュ & 扁平変り二重織 \\
\hline \multicolumn{3}{|c|}{ 縦断面図 } & & $01010 \%$ \\
\hline \multirow{7}{*}{ 組 成 } & \multicolumn{2}{|c|}{ タテ系 } & ポリエステル・細モノ & $\longrightarrow$ \\
\hline & \multirow{2}{*}{ ヨコ系 } & 表 & ポリエステル・モノ & $\longrightarrow$ \\
\hline & & 裏 & ポリアクリル・スパン & - \\
\hline & \multicolumn{2}{|c|}{ ウェブ } & ポリエステル＋ポリアミド & \\
\hline & \multicolumn{2}{|c|}{ タテ系 } & $\longrightarrow$ & 薄手扁平ポリエステル・モノ \\
\hline & \multirow{2}{*}{ ヨコ系 } & 表 & 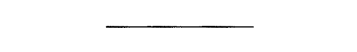 & ポリアクリル・スパン \\
\hline & & 裏 & - & ポリエステル・モノ \\
\hline \multicolumn{3}{|c|}{ さ (mm) } & 1.8 & 1.5 \\
\hline \multicolumn{3}{|c|}{ 通気度 $\left(\mathrm{cc} / \mathrm{min} / \mathrm{cm}^{2}\right)$} & 2,500 & 3,000 \\
\hline
\end{tabular}

表 3 新聞用紙マシンカンバス（代表例）

\begin{tabular}{|c|c|c|c|}
\hline \multicolumn{2}{|c|}{ パ - } & 卜 & 1 5 群用 \\
\hline \multicolumn{2}{|c|}{ 品 } & 号 & FB-801 C \\
\hline \multicolumn{2}{|c|}{ 組 } & 織 & 三 重 織 \\
\hline \multicolumn{4}{|c|}{ 縦 断 面 図 } \\
\hline \multirow{3}{*}{ 組成 } & \multicolumn{2}{|c|}{ タテ糸 } & 扁平ポリエステル・モノ \\
\hline & \multirow{2}{*}{$\exists コ$ 系 } & 表 & ポリアクリル・スパン \\
\hline & & 中·裏 & ポリエステル・モノ \\
\hline \multicolumn{3}{|c|}{ 厚さ $(\mathrm{mm})$} & 1.9 \\
\hline \multicolumn{3}{|c|}{ 通気度 $\left(\mathrm{cc} / \mathrm{min} / \mathrm{cm}^{2}\right)$} & 2,500 \\
\hline
\end{tabular}

スと湿紙との密着性の低下が原因と考えられ，(1)操業 時の湿紙のドローの調整, (2)サクションロールの吸引 圧の調整，(3)抄物毎の PD 温度勾配の設定，などのマ シン面での対応によって解決が計られた。同時に，こ の経験を基にカンバスの，(1)厚さを更に薄くする，(2) 通気度を調整する, (3)摩擦抵抗の少ない表面性に変更 する，などの対策案を確立することもできた。

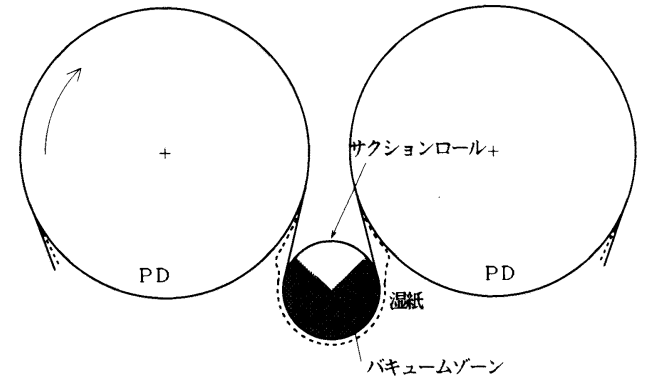

図 10 サクションロール付近での湿紙の膨らみ

まだ使用実績は少ないが現在までのライフサイクル は平均すると 11 1 15 ケ月で，一般の抄紙機とほほ同 等の寿命であった。

使用済みになったカンバスを分析した結果, トー夕 ル単列ドライヤー独特の現象も見受けられるので, 今 後の検討項目として改善したい。

\section{5 ま と め}

紙の伸縮特性の改善が認妨々 亿, 乾燥効率も高く, キャリヤロープを用いずとも通紙が可能なことで操業 性もよく, トータル単列ドライヤーは非常に高い評価 を得た。韓国では 1993 年に稼働したトータル単列ド

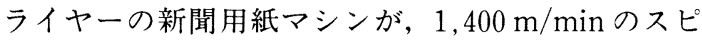
ードで操業している。 
世界的に今後新設される抄紙機は，特別のことがな い限りトータル単列ドライヤーが採用されるものと思 われるので, 更なるカンバスの改善工夫に努力を傾注 したい。

\section{3. カンバスの耳部摩損対策}

カンバスのガイド装置のパームの切損対策などで, パームにセラミックのコーティング品を採用される抄 紙機が増えてきた。

時期を同じくしてカンバスの耳部が摩損し，タテ系 がほつれて繊維が飛散し湿紙に混入して断紙や欠点の 原因となったり, 走行不良によって操業性を著しく低 下させるなどのケースが発生した。抄紙機の高速化や 耳部摩損が比較的発生しやすい薄手カンバスの普及な どもあり，耳部摩損の原因究明と対策を検討した。

\section{1 摩 損原因}

カンバス耳部の摩損形態としては,

(1)耳が溶融し溶融物がパームの表面に焼付いている ケース。

(2)耳部の削れたものが粉体となってパームの表面に 付着しているケース。

(3)継手の部分から数メートル後より発生し，数回の 凹みがあるケース。

(4)耳部が斜めに削れるほど，パームに押し付けられ た形跡が認められるケース。

その要因としては,

(1)セラミックコーティングの影響。

(2)パームがカンバス耳部を押さえる力，いわゆる接 圧が強い。

(3)継手部の部分的な段差によるパームの振動。

(4)ガイド効果不良。

これらの要因が複合的に作用してカンバス耳部の摩 損が発生していることが分かった。特に熱伝導率が低 く摩擦熱が発散されないセラミック製パームを，300 $\mathrm{g}$ 以上の強い接圧で使用されている抄紙機の場合は,

摩損の発生する確立が非常に高かった。

対策としては,

(1)パーム表面材料の改良。

(2)パーム接圧の低減。

(3)パームのセッティングの改良と軽量化。

(4)ガイドロールの配置や信号系の応答速度の見直し。 カンバスメーカーとしては, カンバス耳部の強化を 推進すると共にパーム表面材料の改良に取り組んだ。

\section{2 カンバス耳部の強化による対策}

通常カンバスは耳部を溶着して，さらにエッヂから 約 $20 \mathrm{~mm}$ の幅で, 織物のほつれを止めるため樹脂加
工を施している。先ず検討したのが補強材料を樹脂に 混入する方法である。具体的には，(1)セラミック粉体, (2)カーボンミルドファイバー, (3)テクノーラチョップ ドファイバー，の試作を実施した。

最初にセラミック混入案として珪酸ジルコニアを混 入したものをテストしたが，摩耗脱落したセラミック 自体がアブレッシブ摩耗の研磨剤となることと, 樹脂 との接着が悪く樹脂そのものの強度が低下し, 耐摩耗 性が低下してしまった。

次のカーボンミルドファイバーの場合は効果がなか つた。

最後のテクノーラのチョップドファイバーは効果が あったが, 纎維長が長く樹脂との混合が難しいのと, 織物の中に充填することができず製品として実用化で きなかった。しかし，効果が見られたことから素材と しての性能が確認でき, 耳部の織り込み補強を実用化 する基礎になった。

一方，一連の実験を進めるうち当社で使用中の樹脂 の耐摩耗性も確認でき,さらに耐摩耗性に優れた樹脂 の開発に結び付けることができた。

(1) 耳樹脂の改良

プラスチックカンバスの耳部の処理は熱溶着だけの 物から始まり，(1)ゴム系接着剤，(2)ポリウレタン系接 着凨，(3)エポキシ系接着片と使い分けてきており，今 回の試験でセラミックパームに対して，その耐摩耗性 について性能の違いがあることが判明した。またささ らに耐摩耗性に優れた紫外線硬化型樹脂を開発できた。 これらの耐摩耗性試験結果を図 11 に示す。

今後セラミックパームを使用される抄紙機には，耐 摩耗性を重視した樹脂の選択を行っていく。また，樹 脂の中にシリコン系の潤滑性物質を混入することによ って，耐摩耗性をさらに上げることも可能となった。 この試験結果を図 12 に示す。

\section{（2）特殊繊維による補強}

樹脂の高性能化に加えさらに性能の良い加工方法も 開発した。これはカンバスの耳部に，特に耐摩耗性に 優れたテクノーラ纎維をタテ糸の一部として織り込み, その繊維と親和性の良い樹脂で固める加工方法である。

走行実駼装置でテストの結果, 図 13 の通り摩損対 策に効果的であることが確認できた。補強品の摩損は 補強繊維の無い溶着部分で発生しており，パームが補 強繊維に当たる約 $0.8 \mathrm{~mm}$ のところで摩損がストップ している。

このテクノーラ繊維による補強方法は製造上の制約 が多かったが，摩損对策として大きな効果が期待でき るため, 耳部摩損が発生している抄紙機で実用テスト 
摩耗速度比（樹脂Type-Cを 1 にした比率）

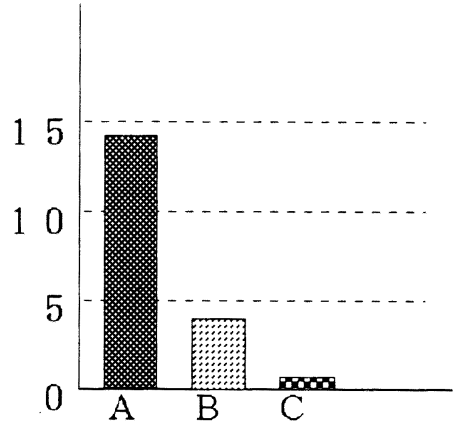

$\begin{array}{ll}\text { 試馻条件: } & \\ \text { サンプル } & \text { BF-207 } \\ \text { パーム } & \text { セラミックコーティング } \\ \text { 接 压 } & 1.95 \mathrm{~kg} \\ \text { 走行速度 } & 600 \mathrm{~m} / \mathrm{min} \\ \text { 走行時間 } & \text { 適時 } \\ \text { Type- } \mathrm{A} & \text { ポリウレタン系樹脂 } \\ \text { Type-B } & \text { エポキシ系樹脂 } \\ \text { Type-C 紫外線硬化型樹脂 }\end{array}$

図 11 各種樹脂の耐摩耗性試験結果

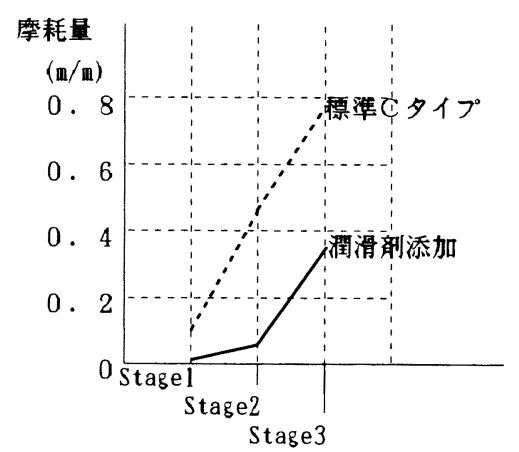

※潤滑剂混入試験はType_Cにて試験

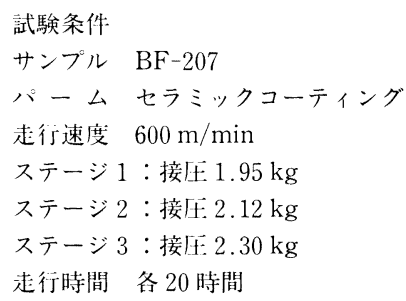

図 12 潤滑剂混入樹脂の耐摩耗性試験結果

を実施した。表 4 の通り実用テストの結果いずれも効 果があり，現在 18 台の抄紙機などで採用されている。

\section{3 パーム表面材料の改良による対策}

低い熱伝導率により高温の摩擦熱が発生し溶融する ことや, 硬いセラミック粒子による切削摩損の対策で, パーム表面材料の検討も実施した。
[特殊繊維補強の耐摩耗性試験結果]

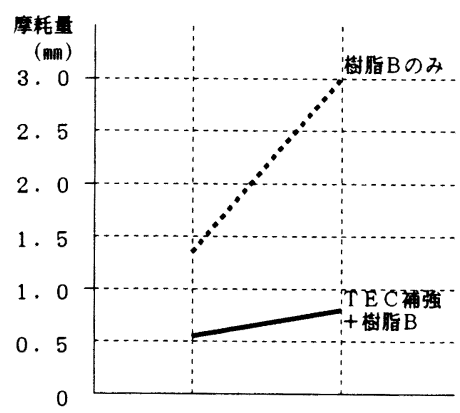

\section{※繊維補強試験はType_Bにて試験}

$$
\begin{array}{ll}
\text { 試験条件 } & \\
\text { サンプル } & \mathrm{HBF}-806 \\
\text { パーム } & \text { セラミックコーティング } \\
\text { 走行速度 } & 600 \mathrm{~m} / \mathrm{min} \\
\text { 接＼cjkstart庄 } & 1.95 \mathrm{~kg} \\
\text { 走行時間 } & \text { ステージ } 1 \\
& \text { ステージ } 2 \\
& \text { 各 } 20 \text { 時間 }
\end{array}
$$

図 13 特殊繊維補強の耐摩耗性試験結果

対策品として，(1)熱伝導率の高いものを混入し熱拡 散を計る，(2)耐摩性の良い材料を用いながら粒子があ まり鋭利にならない，を目標に材料開発と試験を実施 し，カンバスの耳摩損に対して有利な材料を選定する ことにした。

多数試作し，走行試験装置により実験を重ねるうち， 金属系の混合物を溶射したもので期待する材質を得た。 耐摩耗性を受け持つ素材としてニッケルクロム合金, 熱拡散を受け持つ素材としてモリブデン合金，その他 バインダーを適切な粒子サイズと配合比に調整したも のである。表 5 に各種表面処理の摩耗実験デー夕を示 す。

予想される特性として, 開発品 (以下 MCP : metal coating palm) はセラミックの溶射品よりもパ 一ムの耐摩性は若干劣ると思われるが，硬度的には SUS 304 より格段に硬い。また，ハードクロムメッ キより膜厚が十分厚いものが得られ, 熱的な耐久性も 高く実用化が期待できた。

走行実験装置でカンバスの両耳に樹脂加工を施し, 七ラミックパームと MCP で挟む形で摩損実験を実施 したところ図 14 に示す通り，七ラミックパームで摩 耗量は最大部分で約 $7.5 \mathrm{~mm}$, 最少部分で $5.5 \mathrm{~mm}$ で あったが, MCPで同じく $4.0 \mathrm{~mm}, 2.5 \mathrm{~mm}$ となり 摩耗量が減少しているのが確認できた。

現在 12 台の抄紙機で実用テストを実施しているが, 
表 4 特殊䋐維補強反の採用実績

\begin{tabular}{|c|c|c|c|c|c|c|c|c|c|}
\hline 会社 & 工場 & 機号 & 紙の種類 & $\begin{array}{l}\text { スピード } \\
(\mathrm{m} / \mathrm{min})\end{array}$ & 会社 & 工場 & 機号 & 紙の種類 & $\begin{array}{l}\text { スピード } \\
(\mathrm{m} / \mathrm{min})\end{array}$ \\
\hline \multirow{5}{*}{ A } & \multirow{5}{*}{$\mathrm{a}$} & 3 & 塗工原紙 & 900 & \multirow{3}{*}{$\mathrm{D}$} & a & 8 & 上 質 紙 & 900 \\
\hline & & 4 & 上 質 紙 & 1,000 & & $\mathrm{~b}$ & 10 & 塗工原紙 & 1,200 \\
\hline & & 5 & 塗工原紙 & 1,100 & & c & 9 & 微塗工紙 & 1,100 \\
\hline & & 6 & 上 質 紙 & 1,200 & \multirow{3}{*}{$\mathrm{E}$} & a & YN & 新聞用紙 & 1,100 \\
\hline & & コーター & コート紙 & 1,300 & & $\mathrm{~b}$ & $\mathrm{~N}-1$ & 上 質 紙 & 1,000 \\
\hline \multirow{3}{*}{ B } & a & 13 & 塗工原紙 & 1,000 & & c & $\mathrm{N}-4$ & 塗工原紙 & 1,000 \\
\hline & $a$ & コーター & コート紙 & 1,200 & $\mathrm{~F}$ & $\mathrm{a}$ & $\mathrm{N}-3$ & 上質 紙 & 1,000 \\
\hline & $\mathrm{b}$ & 4 & 新聞用紙 & 1,100 & \multirow{2}{*}{ G } & \multirow{2}{*}{$\mathrm{a}$} & 6 & 微塗工紙 & 1,000 \\
\hline $\mathrm{C}$ & $\mathrm{a}$ & 5 & 塗工原紙 & 800 & & & 7 & 微塗工紙 & 1,000 \\
\hline
\end{tabular}

表 5 表面処理の比較

\begin{tabular}{l|c|c|c}
\hline & $\begin{array}{c}\text { 皮膜硬度 } \\
\text { (HV 300) }\end{array}$ & $\begin{array}{c}\text { 耐摩試験 } \\
\text { (摩耗量) }\end{array}$ & 熱伝導率 \\
\hline セラミック & 1,300 & $60 \mu$ & $3 \sim 4$ \\
\hline ハードクロムメッキ & 850 & $95 \mu$ & - \\
\hline SUS 304 & - & - & $15 \sim 16$ \\
\hline $\mathrm{MCP}$ & 960 & $35 \mu$ & $10 \sim 12$ \\
\hline
\end{tabular}

皮膜硬度 : マイクロビッカース硬度

耐摩耗試験：又ガ式摩耗試験 摩耗環 SIC\#320ペーパー

荷 重 $2 \mathrm{kgf}$

摩擦回数 800 回

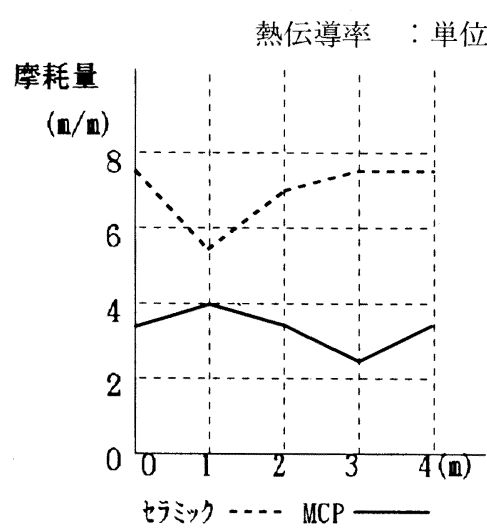

試験条件

サンプル BF-207

パーム セラミックコーティング $\times \mathrm{MCP}$

接 尼 $3.0 \mathrm{~kg}$

走行速度 $600 \mathrm{~m} / \mathrm{min}$

走行時間 20 時間

図 $14 \mathrm{MCP}$ の試験結果
パームの耐久性が向上することに加え，カンバス耳部 の摩損の発生もなく, いずれも順調な状況にあり, 効 果が確認できた。

\section{4. カンバスの污れ対策}

カンバスは使用日数を経るに従って污れて通気度が 低下する。カンバス表面に付着したピッチ類などの原 料污れが成長するにつれ, 紙の品質を低下させたり断 紙の原因にもなる。加えて, 通気度の低下は乾燥効率 に影響を及ぼし蒸気原単位を悪化させる。カンバスの 污れ対策と通気度管理の状況を報告する。

\section{1 カンバス污れの実態}

カンバスの污れは，(1)抄造する紙の種類，(2)原料事 情, (3)設備機械, (4)操業条件, (5)カンバス使用期間, などによって極めて多岐にわたっているが，活れの形 態を大別すると次の通りである。 
(1)古紙からのホットメルトなどのガム状物質が短繊 維を伴い, カンバス表面や組織内に入り目詰り現 象を発生させているケース。

(2)パルプ内の污れ（木材樹脂ピッチ・DIP ピッチ) や添加剤（内添剤・紙力增強剤）が紙粉などと共 に小斑点状にカンバス表面に付着するケース。

(3)中性抄紙に切替後, コートブロークからくるラテ ックス系のピッチや粘着性の強い中性サイズ剤が, カンバスのナックル部分 (タテ糸とヨコ系の織交 点）に付着し成長するケース。

(4)表面サイズ夜やコート液が断紙などの際にカンバ ス一面に付着するケース。

(5)潤滑油に紙粉や塵などが混入し，カンバス耳部全 周が目詰りしているケース。

\section{2 カンバスの污れ防止効果}

カンバスは一定の張力によって湿紙を PD に圧着し ているのであり，湿紙に粘着物質が点在すればカンバ スに移行するのは当然である。

最初に接圧の最も高いナックル部分に微細な状態で 移行した污れ物質は, 微小繊維なども伴ってカンバス ロールに転移する。污れは湿紙からカンバス，カンバ スからロール, 逆にロールからカンバス, と転移成長 を繰り返し熱によって強固になりトラブルを発生させ る。

カンバスの污れ防止効果のポイントは, 湿紙からの 污れの移行を押えると共に, 転移するロール類を工夫 することにある。

(1) ニードルカンバスの採用

ニードルカンバスは, 表面にナックルがなくウェブ 層で構成され最も平滑性に優れているため, 湿紙を均 一に圧着することができる。ナックルが解消したこと により, 湿紙からの污れの移行が減少する。更に柔軟 性とクッション性があり, 印刷用紙マシンのウェット エンドでの採用例が非常に多いのは周知の通りである。 ニードルカンバスは各種のウェブを配合することが でき，親水性や多孔質の繊維をウェブに配して，カン バス表面に水の分子による被膜を形成して粘着物質の 付着を防ぐ工夫も可能である。

(2) カンバスロールのインサイド化

図 15 に示すよjに，カンバスのペーパーサイド （接紙面）とカンバスロールはストレッチロールまた はその付近で接触している。

この状態であれば前記の通りカンバスとロール間で 污れの転移が繰り返される。

これを図 16 の通り，ロールを全てカンバスのイン サイドに設置し，ペーパーサイドにロールが接触しな

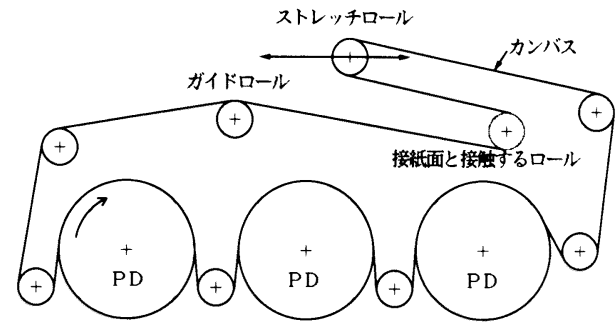

図 15 接紙面にロールが接触するラン

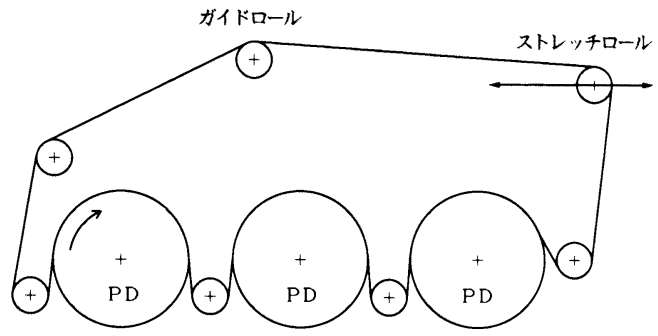

図 16 改造によりインサイド化されたラン

いように改造された例がある。

カンバスロールのインサイド化は予想以上に効果が あった。特に上部パートはロールから湿紙への落下卜 ラブルが解消したこともあり，図 17 の通り新設マシ ンでも採用されている。このカンバスロールのインサ イド化によって，カンバスが全く污れなくなった訳で はなく，粘着力のある物質の付着は依然としてあった。 しかし，污れを成長させる場所をなくしたことで，污 れによるトラブルの発生回数は確実に減少した。

既設マシンの場合，条件によってはこの方法が採用 できないケースもあり，ロールで污れを成長させない 別の方法も採用されている。

(1)カンバスロールの表面処理

・フッ素樹脂のコーティング加工又はフッ素テー プの貼り付け。

・ゴム系樹脂加工

・グルーブド加工

・フィンロールの採用

(2)カンバスロールにドクターとセーボールの設置

(3)ブラシロールやブラシボードの設置

\section{3 カンバスの洗浄}

カンバスはその原因が何であれ污れていくのは避け られず，カンバスを効率よくクリーニングする方法も 確立しつつある。

洗浄方法や洗浄圧について, 実施例を表 6 の通りま とめた。但しニードルカンバスは, ウェブ損傷や水切 


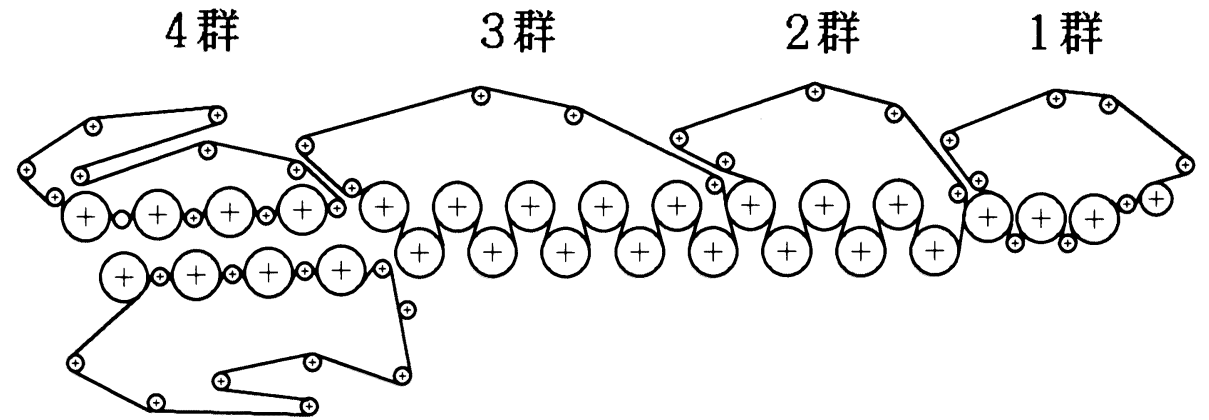

図 17 新設マシンのインサイド化（1～3 群)

表 6 カンバス洗浄方法と実施例

\begin{tabular}{|c|c|c|c|}
\hline \multicolumn{2}{|l|}{ 洗 浄 方 } & \multirow{2}{*}{$\begin{array}{l}\text { 洗浄圧力 } \\
\left(\mathrm{kg} / \mathrm{cm}^{2}\right)\end{array}$} & \multirow{2}{*}{ 実 施 例 } \\
\hline 業 中 & 休 転 時 & & \\
\hline & $\begin{array}{l}\text { 固定シャワー又は摺動 } \\
\text { シャワー。ノズルピッ } \\
\text { チは } 10 \sim 50 \mathrm{~cm}\end{array}$ & 水: $10 \sim 30$ & $\begin{array}{l}\text { 比較的污れの少ないパートで紙粉 } \\
\text { などの除去が可能。 }\end{array}$ \\
\hline $\begin{array}{l}\text { 圧縮エア一の吹き付け。ノズ } \\
\text { ルを幅方向にトラバース。 }\end{array}$ & $\begin{array}{l}\text { 高圧水による洗浄と圧 } \\
\text { 縮エアーでの水分の除 } \\
\text { 去。ノズルを幅方向に } \\
\text { トラバース。 }\end{array}$ & $\begin{array}{l}\text { エアー }: 5 \sim 7 \\
\text { 水 } \quad: 30 \sim 60\end{array}$ & $\begin{array}{l}\text { 印刷用紙・新聞用紙マシンでの実 } \\
\text { 施例がある。紙粉の除去と通気度 } \\
\text { の維持が目的。 }\end{array}$ \\
\hline $\begin{array}{l}\text { 圧縮エアーと蒸気の吹き付け。 } \\
\text { ノズルを幅方向にトラバース。 }\end{array}$ & 同上 & $\begin{array}{l}\text { エアー: } 5 \sim 7 \\
\text { 蒸 気 : }: 2 \sim 4 \\
\text { 水 } \quad: \quad 30 \sim 60\end{array}$ & $\begin{array}{l}\text { エアーに加え質量の高い蒸気を併 } \\
\text { 用し衝撃を強め污れを操業中に除 } \\
\text { 去する。ウォーターマークの心配 } \\
\text { も無くウェットエンドのパートで } \\
\text { も操業中に洗浄が可能で上質紙や } \\
\text { コート原紙マシンで実施例がある。 }\end{array}$ \\
\hline $\begin{array}{l}\text { 高圧蒸気の吹き付け。 } \\
\text { ノズルを幅方向にトラバース。 }\end{array}$ & 同上 & $\begin{array}{l}\text { 蒸 気: } 8 \\
\text { 水 } \quad: 30 \sim 60\end{array}$ & $\begin{array}{l}\text { 温度と衝撃力を利用した洗浄で操 } \\
\text { 業中に実施。オンマシンコート紙 } \\
\text { で実施例がある。 }\end{array}$ \\
\hline $\begin{array}{l}\text { 高圧水での洗浄と圧縮エアー } \\
\text { での水分の除去。 } \\
\text { ノズルを幅方向にトラバース。 }\end{array}$ & 同 & $\begin{array}{l}\text { 水 圧: } 60 \sim 110 \\
\text { エアー: } 5 \sim 7\end{array}$ & $\begin{array}{l}\text { 段ボール原紙マシンでは操業中に } \\
\text { 洗浄するケースが多いが, 洋紙マ } \\
\text { シンではゲートロール後で一部実 } \\
\text { 施している程度で殆どが休転中に } \\
\text { 洗浄。 }\end{array}$ \\
\hline $\begin{array}{l}\text { 薬品をカンバスに直接噴霧し, } \\
\text { 高圧水と圧縮エアーを併用。 } \\
\text { 薬品・高压水・エアーともに } \\
\text { ノズルで幅方向にトラバース。 }\end{array}$ & 同上 & 同上 & $\begin{array}{l}\text { 薬品と高圧水・エアーの併用によ } \\
\text { クガム状物質の除去も可能, 段ボ } \\
\text { ール原紙マシンで実施している。 }\end{array}$ \\
\hline
\end{tabular}


れの悪さという面があり, 高圧水での洗浄は適さない。 高圧洗浄する抄紙機ではモノフィラメント製カンバス が適し, 最近は接触面積が広く平滑性に優れた扁平力 ンバスが，サイズプレス後などのパートに採用される ケースが多い。段ボール原紙マシンでは, (1)モノカン バス, (2)洗浄装置, (3)薬品, (4)ドクター, (5)ブラシロ 一ル，などを併用してガム状ピッチを除去している。

フッ素樹脂入りのポリエステル製モノカンバスもあ るが, 今後とも污れないカンバスの開発は継続的なテ ーマとして研究を進めていく。

\section{4 カンバス通気度の測定}

一般例であるがカンバス通気度は，図 18 に示す通 り掛入れ後経時的に低下亦る。污れの付着しやすい抄 紙機では，取替え時期になるとカンバス通気度が $0 \mathrm{cc}$

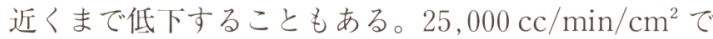
スタートした通気度が大幅に低下することから，乾燥 性に影響が出てくる可能性が非常に高い。

主力乾燥ゾーンのカンバスを一度にまとめて取替え た際などに，乾燥性が向上した事例をよく耳にするこ とがある。(1)乾燥性が低下した，(2)原因不明の水分プ ロファイルの乱れがあった, (3)シングルパートで湿紙 がカンバスから離れしわが発生した，などの際に使用 中のカンバス通気度を測定し管理することが必要とな つてきた。

写真 1 がポータブルの通気度テスターである。この テスターで使用中のカンバス通気度を休転時に定期的 にチェックすることができる。大幅な通気度低下や幅 方向にバラツキのあるカンバスを発見した場合に，洗 浄の強化や取替えなどの判断基準の参考にするなどの 保守管理技術が，抄紙機の安定操業に不可欠である。

\section{5.おわりに}

カンバスは長期間使用される用具である。現在，長 いパートでは18ケ月以上, 短いパートでも8〜10ケ 月のライフサイクルが一般的である。今後も新素材を 投入した品種の開発は進み, 更にライフの延長が考え られる。寿命が長いために, 使用期間中の保守管理を いかにうまく実施するかによって，抄紙機の安定操業 が得られるものと確信している。

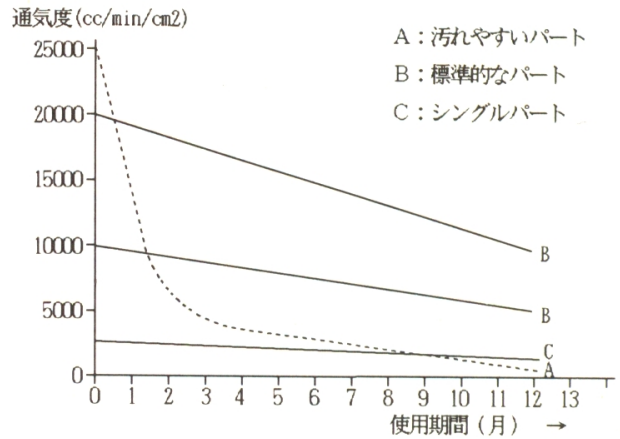

図 18 通気度の低下例

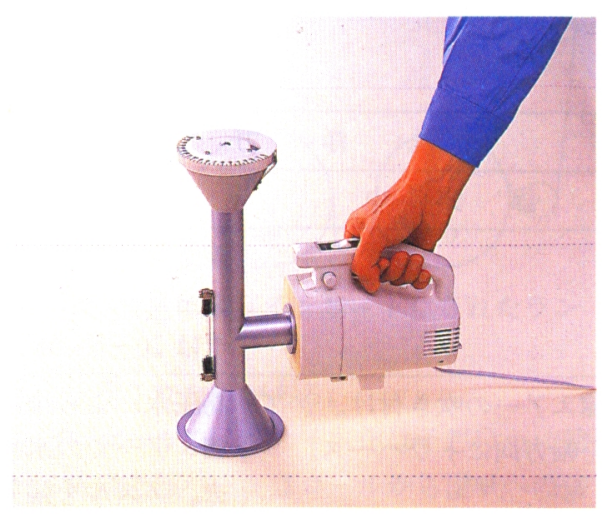

写真 1 通気度チェック

ポータブル通気度テスター

今回報告した以外にも, 効果的なライフチェック方 法やカンバステンションの測定方法が確立できている。 さらに総合的なドライパートの診断材料となる, 各種 計測やサーモビジョンによる湿紙温度の測定などを積 極的に実施する方針である。

多筒式ドライヤーが定着して以来, 変化の少なかっ たドライパートにも単列ドライヤーなど設備面の多様 化が進むものと思われる。

設備にマッチしたカンバスの新製品の開発は勿論の こと, 取扱い方法や保守管理技術などソフト面の改善 工夫にも努力を傾注していく所存である。

\section{引用文献}

大森良行：紙パルプ技術協会誌 47,3 号 